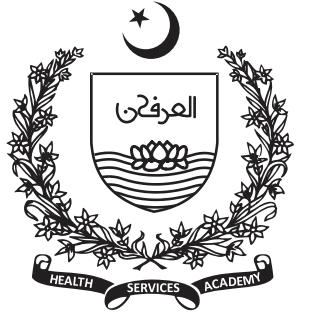

Institute of Health Management- Dow University of Health Sciences, Karachi, Pakistan.

Corresponding Author: Hira Maqsood Email: hera_khan@outlook.com.

\title{
Disparity in Populace Phenotype Impels Predisposition to Variations in Health Status
}

Hira Maqsood

\section{Abstract}

Background: The disparity in populace phenotype, embracing stature and pigmentation, drives of internal physiological constituent and adaptation to the external environment, impel variations in populace health status. The study tends to explore how significantly populaces phenotype influenced by internal or external exposures, and how effectually it prognosticates predisposition to variant health states.

Methods: Ecological study encompassing twenty states residing on antipodes (North and South) endures distinct exposures, exhibit disparate phenotypes, execute different health status. Each State selected employing non-proportion quota sampling, standing extreme on either stature or pigmentation, residing in cold or hot region, contrasted on considered variables embracing UV-index, malnutrition, healthy life expectancy, fertility rate, natural increase, and top five causes of mortality. All computation, analysis, and interpretation perform employing MS-EXCEL. The complete compilation phase last from March to June 2019.

Results: Findings reveal a strong association between exposures and phenotypes, UV-index and pigmentation $(r=0.96)$, malnutrition and stature $(r$ $=-0.81$ ). Stature descends and pigmentation ascends along the latitude (North to South). Populace light pigmentation tall stature executes healthy prolong life span contrast to deep pigmentation standing short. Cardiac and cancer diseases significantly reported among statured nations. While high susceptibility to Influenza/ Pneumonia, and HIV/AIDS observe in pigmented nations.

Conclusion: Decisively homo sapiens phenotypes inordinately servile to internal and external exposures effectually prognosticate predisposition to distinct health states. Enforcement of measures mitigating populace internal and external exposure can elicit desire output in phenotype and outcomes in health status.

Keywords: Stature, pigmentation, healthy life expectancy, UV index, malnutrition

\section{Introduction}

$\mathrm{H}$ ealth degeneration is a growing global concern. About four-fifths of the world populace execute life span less than seven decades. Health status is briefly defined by birth rate, death rate, and healthy life expectancy, likely to vary across the globe. (1)

People phenotype characterize by stature, pigmentation, mass, (2) drives of an internal physiological constituent, and adaptation to the 
external environment. Populace dwelling in a region, abide by intense UV radiations, assumes deep pigmentation (3). In contrast, the nations in territories bearing low UV-index, reveal light pigmentation. (4) The increase reliance on healthy regimen, including the salubrious nutrition, concomitant tall standing on stature whereas malnutrition account for short stature. The differences in these phenotypes determine the susceptibility or insusceptibility to varied benign and malignant disease. The high melanin induces low sensitivity to heat and cold. (3) Light skin administers adequate Vit D concentration at site of UV exposure, reduce susceptibility to various fatal diseases. (4) The short statures exhibit short pathways turn more responsive to external stimuli are less afflicted by chronic diseases. (5) While tall standing steers low vulnerability to respiratory issues. (6) Thus, each phenotype precursor some health pros and cons.

This study tends to expatiates the disparities in populace phenotype, embracing stature and pigmentation, ensues of internal or external exposure, and considering the differences prognosticates predisposition to variant health states.

\section{Methodology}

The ecological study encompasses twenty states residing on antipodes (North and South), endure distinct exposures, exhibit disparate phenotypes, and execute variant health status.

Each State selected employing non-proportion quota sampling, standing extreme on either stature (measures mean of two genders in $\mathrm{cm}$ ) or pigmentation (estimated using a chromatic color scale) (7) residing in a cold or hot region, contrasted on considered variables embracing UV index (uv), malnutrition (m), fertility rate(fr), natural increase (ni, difference of birth rate and death rate) (8), healthy life expectancy, and top 5 causes of mortality(by \%), reflecting populace succinct health profiles.

Calculation of correlation coefficient, stature, and pigmentation assessed against malnutrition and UV index respectively. Equation of multiple regression formulated, stature, and pigmentation along with estimator prognosticate healthy life expectancy. Compliance to phenotypes each considered variable statistically analyzed whereas the top 3 causes of mortality shortlisted by multiplying assign weight 5 to 1 in descending order to the frequency of occurrence.
Also, the most critical causation of mortality assessed in relation to phenotypes.

Study wears the essence of both qualitative and quantitative research. Derive most figurative data of four main sources including World life expectancy, (1) NCD-RisC,( 9) Human Displacement Map of the World, (10) Weather Atlas, (11), FAO,(12) offering ease of accessibility, availability, and accuracy.

Perform all computation, analysis, and interpretation employing MS EXCEL. The complete compilation phase lasts for 4 months dated March to June 2019. Relatively smaller sample size bearing $10 \%$ (20) representation for entire world states $100 \%$ (195) disproportion sampling along with embedded selection bias, considering only tall or short stature, dark or light pigmentation, residing in the cold or hot region, ignoring the other possibilities, are some limitations to generalization.

The study intends to seek responses to the following research question:

How significantly populace phenotype influenced by internal or external exposure?

How effectually populace phenotype prognosticate predisposition to variant health states?

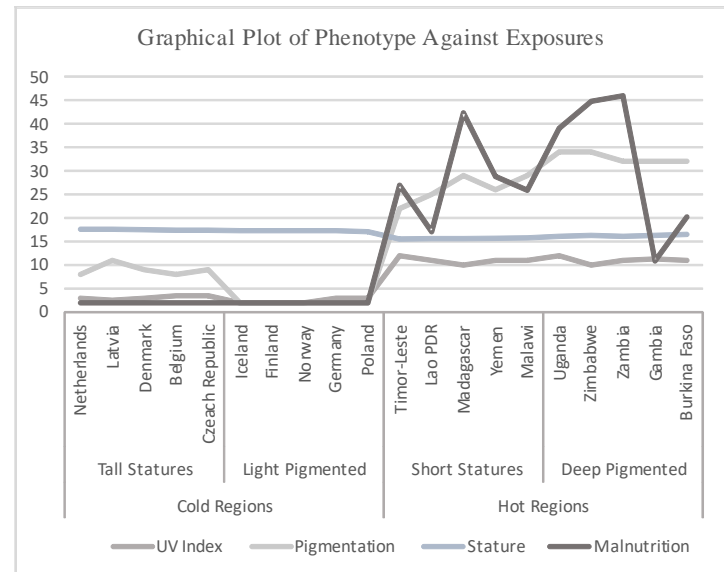

Figure 1. Note: Height $(\mathrm{cm})$ is adjusted by dividing with 10, Malnutrition for cold region exist below 2.5.

\section{Results}

The cold climes mostly concentrate by nations endure low UV index ( $u v_{a v g}=3$ ) comrade's light pigmentation, administers healthy nutrition $\left(\mathrm{m}_{\text {avg }}=2\right)$ ensure tall standing on stature. In contrast, hot sunny region resides by nations, bear intense UV radiation ( $\mathrm{uv}$ avg =11) exhibit tan to dark pigmentation, excessively 
report malnutrition $\left(\mathrm{m}_{\mathrm{avg}}=30.5\right)$ reprehensible for low to moderate standing on stature. Findings indicate a strong correlation between UV index and pigmentation $(\mathrm{r}=0.96)$, malnutrition and stature $(\mathrm{r}=$ 0.81) (Figure 1) Stature likely to descend and pigmentation ascend along the latitude from North to South.

Table 1. Estimating Healthy Life Expectancy

Regression Analysis

Healthy Life Expectancy $=39+0.2$ Stature - 0.5 Pigmentation

$\begin{array}{llll}\text { Multiple R } & 0.98 \quad \text { Adjusted R Square } & 0.95\end{array}$

R Square $0.95 \quad$ Standard Error

1.8

Computed F:180 Critical Value of F: 3.59

Significance of F: $<0.00$

Stature positively $(t=2.13, t(0.025)= \pm 2.11 \mathrm{p}<0.05$, C.I $=95 \%)$, pigmentation negatively $(\mathrm{t}=-9.03, \mathrm{t}(0.025)$ $= \pm 2.11 \mathrm{p}<0.05$, C.I $=95 \%$ ) associates healthy life expectancy. (Table 1) Populace light pigmentation high standing on stature often execute healthy prolong life span of 7 decades contrast to 5 decades by deep pigmentation standing below mean stature. (Table 2, Table 3)

Mean fertility rate apparently high among deep pigmented ( $\mathrm{fr}=5)$, short stature ( $\mathrm{fr}=4$ ) populaces than light pigmented ( $\mathrm{fr}=2)$ tall statures ( $\mathrm{fr}=2)$. Approximately $56 \%$ high fertility rate in hot than cold regions.

Table 2. Cold Region Populace Succinct Health Profiles

\begin{tabular}{|c|c|c|c|c|c|c|c|c|c|c|c|}
\hline \multirow{3}{*}{$\begin{array}{l}\text { SELECTED } \\
\text { STATES }\end{array}$} & \multirow{3}{*}{ 言 } & \multirow{3}{*}{ 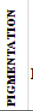 } & \multirow{3}{*}{$\begin{array}{c}\text { HEALTHY } \\
\text { LIFE } \\
\text { EXPECTANCY }\end{array}$} & \multirow{3}{*}{$\begin{array}{l}\text { FFRTILITY } \\
\text { RATE }\end{array}$} & \multirow{3}{*}{$\begin{array}{l}\text { NATURAL } \\
\text { INCREASE } \\
\text { RATE } \\
(\%)\end{array}$} & \multicolumn{5}{|c|}{ TOP FIVE CAUSES OF MORTALITY } & \multirow{2}{*}{$\begin{array}{c}\text { DISEASE } \\
\text { ABBREVIATION }\end{array}$} \\
\hline & & & & & & \multicolumn{5}{|c|}{ (Assign Wg $x$ Frequency of Occurrence) } & \\
\hline & & & & & & 5 & 4 & 3 & 2 & 1 & Alzheimer's 'Dementia \\
\hline \multicolumn{11}{|c|}{ COLD REGIONS } & $\mathrm{CHD}$ \\
\hline Netherlands & 176 & 8 & 72 & 2 & 0.2 & CHD & AL/D & LuC & $\mathrm{s}$ & LD & Coronary Heart Diseast \\
\hline Latvia & 176 & 11 & 67 & 2 & -0.5 & $\mathrm{CHD}$ & $\mathrm{s}$ & LuC & CRC & $\mathrm{I} / \mathrm{H}$ & CRC \\
\hline Denmark & 175 & 9 & 72 & 2 & 0.0 & CHD & LD & LuC & ALL $D$ & $\mathrm{~s}$ & Colon-Rectum Cancers \\
\hline Belgium & 174 & 8 & 72 & 2 & 0.2 & $\mathrm{CHD}$ & ALD & $\mathrm{s}$ & LuC & LD & $\mathrm{H}$ \\
\hline Creach Republic & 174 & 9 & 69 & 2 & -0.1 & $\mathrm{CHD}$ & $\mathrm{s}$ & LuC & LD & CRC & Hypertension \\
\hline Mean & 175 & 9 & 70 & 2 & -0.04 & & $\mathrm{CHD}$ & $\mathrm{s}$ & LuC & & $\mathrm{L} / \mathrm{H}$ \\
\hline Iceland & 173 & 2 & 73 & 2 & 0.7 & CHD & ALD & $\mathrm{s}$ & LuC & LD & Inflammatory Heart \\
\hline Finland & 173 & 2 & 72 & 2 & 0.1 & $\mathrm{CHD}$ & ALD & $\mathrm{s}$ & LuC & $\mathrm{CRC}$ & LuC \\
\hline Norway & 173 & 2 & 73 & 2 & 0.4 & CHD & ALD & $\mathrm{s}$ & LD & $\mathrm{LuC}$ & Lung Cancer \\
\hline Germany & 173 & 2 & 72 & 2 & -0.3 & $\mathrm{CHD}$ & $\mathrm{s}$ & LuC & LD & AL/D & LD \\
\hline Poland & 171 & 2 & 69 & 1 & -0.9 & CHD & $\mathrm{S}$ & LuC & AL/D & $\mathrm{I} / \mathrm{H}$ & Lung Disease \\
\hline Mean & 173 & 2 & 72 & 2 & 0 & & $\mathrm{CHD}$ & $\mathrm{s}$ & ALD & & $\mathrm{s}$ \\
\hline & & & & & & & & & & & Stroke \\
\hline
\end{tabular}

Source: World life expectancy,2017 *,NCD-RisC ,2016*, Human Displacement Map of the World,2008*.

The estimated population growth rate, strikingly high among deep pigmentation (ni avg=2.8), short heights (ni avg $=2.5$ ) and alarmingly low in light pigmentation $\left(\mathrm{ni}_{\text {avg }}=0\right)$, tall statures $\left(\mathrm{ni}_{\text {avg }}=-04\right)$. The manifestation of clear inclination in natural increase observes among the nations from north towards south. (Table 2, Table 3)

Table 3. Hot Region Populace Succinct Health Profiles

\begin{tabular}{|c|c|c|c|c|c|c|c|c|c|c|c|}
\hline \multirow{3}{*}{$\begin{array}{l}\text { SELECTED } \\
\text { STATES }\end{array}$} & \multirow{3}{*}{\multicolumn{2}{|c|}{ 言 }} & \multirow{3}{*}{$\begin{array}{l}\text { HEALTHY } \\
\text { LIFE } \\
\text { EXPECTANCY }\end{array}$} & \multirow{3}{*}{$\begin{array}{l}\text { FERTILITY } \\
\text { RATE }\end{array}$} & \multirow{3}{*}{$\begin{array}{c}\text { NATURAL } \\
\text { INCREASE } \\
\text { RATE } \\
(\%)\end{array}$} & \multicolumn{5}{|c|}{ TOP FIVE CAUSES OF MORTALITY } & \multirow{2}{*}{$\begin{array}{c}\begin{array}{c}\text { DISEASE } \\
\text { ABBREVIATION }\end{array} \\
\mathrm{A}\end{array}$} \\
\hline & & \multirow{2}{*}{ 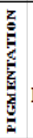 } & & & & \multicolumn{5}{|c|}{ (Assign Wg $x$ Frequency of Occurrence) } & \\
\hline & & & & & & 5 & 4 & 3 & 2 & 1 & Accident \\
\hline \multicolumn{11}{|c|}{ HOT REGIONS } & BT \\
\hline Timor-Leste & 155 & 22 & 59 & 5 & 2.8 & TB & $1 \& P$ & CHD & S & BT & Birth-Trauma \\
\hline Lao PDR & 156 & 25 & 58 & 3 & 1.6 & $\mathrm{CHD}$ & s & $I \& P$ & TB & $\mathrm{LiC}$ & $\mathrm{DD}$ \\
\hline$\angle$ Madagascar & 156 & 29 & 58 & 4 & 2.5 & $I \& P$ & S & TB & $\mathrm{DD}$ & $\mathrm{CHD}$ & Diarrheal Disease \\
\hline Yemen & 157 & 26 & 55 & 4 & 2.2 & $\mathrm{CHD}$ & s & $I \& P$ & LBW & A & $I \& P$ \\
\hline Malawi & 158 & 29 & 56 & 6 & 3.3 & AIDS & $I \& P$ & $\mathrm{DD}$ & M & CHD & Influenza \& Pneumonia \\
\hline${ }^{\vec{v}}$ Mean & 156 & 26 & 57 & 4 & 2.5 & & $I \& P$ & CHD & S & & $\mathrm{LiC}$ \\
\hline Uganda & 161 & 34 & 55 & 6 & 3.3 & AIDS & $I \& P$ & $\mathrm{DD}$ & M & S & Liver Cancer \\
\hline Zimbabwe & 163 & 34 & 54 & 4 & 2.4 & AIDS & $I \& P$ & A & DD & LBW & LBW \\
\hline Zambia & 161 & 32 & 54 & 6 & 2.9 & AIDS & $I \& P$ & $\mathrm{DD}$ & M & $\mathrm{CHD}$ & Low Birth Wg \\
\hline Gambia & 163 & 32 & 54 & 4 & 2.2 & $I \& P$ & AIDS & s & CHD & LBW & M \\
\hline Burkina Faso & 165 & 32 & 53 & 6 & 3.0 & $I \& P$ & M & $\mathrm{DD}$ & CHD & LBW & Malaria \\
\hline \multirow[t]{2}{*}{ Mean } & 163 & 33 & 54 & 5 & 2.8 & & $I \& P$ & AIDS & $\mathrm{DD}$ & & TB \\
\hline & & & & & & & & & & & Tuberculosis \\
\hline
\end{tabular}

Source: World life expectancy,2017 *, NCD-RisC ,2016*, Human Displacement Map of the World,2008*.

Coronary Heart Disease, Stroke, Alzheimer's/Dementia, significantly contributes to mortality among light pigmented tall nations residing in cold regions. While high mortality excessively ensues of Influenza and Pneumonia, HIV/AIDS, Coronary Heart Disease, Diarrheal Disease among short stature swarthy occupying hot territories. (Table 2, Table 3)

A comparison of significant causation of mortality based on phenotype considerably corroborates the above findings. (Figure 2) coronary heart disease and Stroke, reprehensible for $52 \%$ and $18 \%$ greater mortality in tall stature than nation standing short. Alzheimer's/Dementia execute critical figures in Caucasians, $50 \%$ high than deeply pigmented nations. While HIV/AIDS is considerably conspicuous in swarthy, $100 \%$ above than lightly pigmented nations. Influenza and Pneumonia afflict a large proportion of populaces, report $73 \%$ greater fatalities in deep pigmentation than light, and $56 \%$ greater in short than tall statures. (Figure 2) 


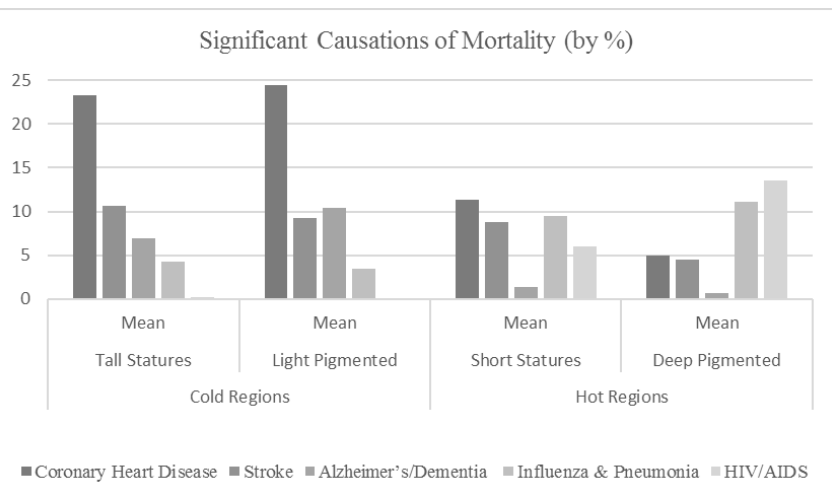

Figure 2. Comparison of significant causation of mortality based on phenotype

\section{Discussion}

The disparity in populace phenotypes embracing stature and pigmentation ensues of internal physiological constituent and adaptation to environmental exposure, impel predisposition to distinct health states. Usually, nations enduring cold climes, administer healthy regimens, execute tall stature, and light pigmentation, in contrast to nations occupying the hot tropical region, suffer high UV index and malnutrition, stands low to moderate on stature and tan to dark on pigmentation.

The European States, light pigmented tall stature nations embodying Netherland, Iceland, Switzerland executes prolong disease-free life span (Healthy life span $>70$ yrs.) whereas Malawi, Sierra Leone, Zimbabwe, deep pigmented short stature African States live far below the mean life expectancies (Healthy life span $<60$ yrs.). $(9,10)$ The former States experience 3 times fewer fatalities than the later States.

(13)

Globally, Netherland males and Latvia females stand tallest while, Timor-Leste males and Guatemala females stand shortest on stature.(6) The estimated average height for the world population is $1.65 \mathrm{~m}$, $1.71 \mathrm{~m}$ in males, and $1.60 \mathrm{~m}$ in females.(14) Mean male stature $(1.71 \mathrm{~m}, \pm 0.02)$ constitute of $44 \%$ tall $(>1.73 \mathrm{~m}), 30$ $\%$ intermediate $(1.69 \mathrm{~m}$ to $1.73 \mathrm{~m})$ and $26 \%$ short $(<1.69 \mathrm{~m})$ individuals.(14) Similarly mean female stature $(1,60 \mathrm{~m}, \pm 0.02)$ derive of $39 \%$ tall $(>1.62 \mathrm{~m}), 32 \%$ intermediate $(1.58 \mathrm{~m}$ to $1.62 \mathrm{~m})$ and $29 \%$ short $(<1.58 \mathrm{~m})$ individuals.(14) Tall statures mostly concentrate in cold European states while short in hot Asia and Africa.

Growth hormones stimulate cartilages reprehensible for musculoskeletal configuration attributes tall or short statures. Healthy nutrition and nourishment strongly determine growth hormones secretion, about $88 \%$ to $99 \%$ of height features are hereditary while $20 \%$ to $40 \%$ modified by healthy regimens. (15) Every extra intake of $100 \mathrm{kcal}$ in the early eighteen years facilitates 0.03 inches increase in stature. (15)

Finland, Latvia, Netherland significantly inhibits malnutrition, secure tall stature while Central African Republic, Sierra Leone, Madagascar characterizing African territories, suffers extreme, stand below mean stature. (12) Poor nutrition one major cause foments height retardation, afflicts every one-third child in Sub Saharan Africa and reprehensible for $33.2 \%$ of stunting. (16).

Whereas the levels of growth hormone and cell proliferation positively associate cancer rates. (17) Estimated $20 \%$ to $40 \%$ increased risk of developing cancer among tall statures, (6) Every $10 \mathrm{~cm}$ height above-average supplement risk of cancer by $11 \%$ in males and $18 \%$ in females. (18) Also, $10 \mathrm{~cm}$ increase in stature accompany risk of lung cancer, $9 \%$ in males and $4 \%$ in females. The finding particularly significant in European and Asian territories. (19) The increasing number of mortalities accruing among tall stature nations including Netherland, Denmark, Serbia, corroborate the sufferance of Lung Cancer. (1)

Venous Thromboembolism (VTE), 2.57 times more frequently encountered in tall statures, (18) every 10 $\mathrm{cm}$ above average height comrades 30 to $40 \%$ increase risk in long lower limbs withstands high gravitational forces resisting venous flow.

The study suggests tall statures with large venous pathways, surface area, and hydrostatic pressure excessively prone to atrial fibrillation. (20) Results high incidence of stroke and heart disease. (18). Coronary heart disease, convicts large proportion of tall populaces, reports strikingly higher mortality rates in Ukraine and Belarus, 0.33 and 0.31 per 100 individuals each measure $1.7 \mathrm{~m}$ tall $(1,9)$

In contrast, short statures appear more vigorous, process sensory signal $10 \mathrm{sec}$ earlier than tall individuals. (5) Standing below mean stature complement low sensitivity to sun radiations, the rapid discharge of heat, less vulnerability to heatstroke, experience $20 \%$ less susceptibility to skin cancer. (6) Short stature comrade's greater stability in the functionality of vital organs with advances in age.

Females standing low on stature, with small body configuration often vulnerable to short gestation, pre and post-pregnancy complexities. (6) Administers 
twice the fertility rate than tall females in some continents prone to menopausal issues, breast, and ovary cancer (6)

The world population constitutes approximately $16 \%$ Caucasian and 15\% Swarthy. (21) Swarthy occupies hot African territories enduring intense UV exposure than Caucasians residing mostly in the cold European region. Accordingly, Uganda, Zimbabwe execute the deepest pigmentation whereas Iceland, Finland the lightest. (10) Pigmentation determines the proportion of eumelanin and pheomelanin. An increased proportion of eumelanin ensues deep pigmentation while pheomelanin responsible for light pigmentation. The proportion of these pigmentations often correlate with UV exposure. (22) Skin pigmentation observes between 1 to 36 on the chromatic color scale reflects shades of lightness (1 to 12), tanned (12 to 24$)$, and darkness (24 to 36). (10)

Melanin exhibits a significant role in regulating each basic unit of life, cells constituting the entire human body. The concentration of melanin facilitates the synthesis of energy through water dissociation independent of vascular pathways. Derive energy ensures the functionality of vital organs and systems.

(23)

Pigmented skin rich in melanin, meant to boost immunity against a host of disease. Endure high resistance to parasitic infection, induce low sensitivity to heat and cold. (3)

Pigmentation comrades' lower rates of visual impairment. Confronts lower issue of temporary hearing loss accruing of noise exposure. (3) Impels low rates of osteoporosis than Caucasian. Deep pigmentation triggers 50 times reduce risk of developing cancer among swarthy. (3)

Pigmentation less prone to a neurological disorder. A study incorporating 122 subjects report $50 \%$ greater prevalence of Alzheimer's in Caucasians than Swarthy. (24) CNS extensively submissive to melanin for effective regulation, accounts for high Alzheimer related mortality rates (per 1000) in lightly pigmented nations embracing Turkey (0.58), Lebanon (0.56) Libya (0.53) Finland $(0.51) .(1,10)$

Vit D derivative of UV exposure, essential for healthy nourishments, execute an autoimmune response to infection, help prevent the incidence of fatal and nonfatal disease. Light pigmentation more responsive to UV exposure, trigger 50k IU Vit D within $30 \mathrm{~min}$ of sunbath than $8 \mathrm{k}$ to $10 \mathrm{k}$ IU by deep pigmentation. (4)
On the other hand, inordinate melanin, natural sunscreen, often inverse Vit D production reprehensible for Vit D deficiency. Reportedly 53\% to $76 \%$ of dark pigmentated nations frequently found deficit in Vit D concentration, residing close to the equator. (25)

The presence of the Vit D receptor in each body cell signifies the role of Vit D in the regulation of physiological processes. Vit $\mathrm{D}$ inadequacy result increase risk of $\mathrm{TB}$, hepatitis $\mathrm{C}$ virus, and AIDS criticality. (26)

HIV/AIDS, intimate association with Vit D deficiency, targets large populaces in regions, bearing pigmentation indices above 27 on chromatic color scale, including Lesotho (0.58), Swaziland (0.38), Mozambique (0.3), Zimbabwe (0.28), report high mortality rate per 100 individuals. $(1,10)$

Influenza leading causation of mortality globally inflicts 0.2 to 0.6 million people annually. (27) Vit D deficiency entices twice Influenzas and pneumoniarelated mortalities in children exhibiting dark pigmentation. (28) Most conspicuous figures observed in pigmented nations, Nigeria, and Sierra Leone, report highest mortality rate (100), 0.25 and 0.22 , respectively. (1)

Vit D insufficiency, also held reprehensible for increased incidence of diarrheal diseases. (29) The $8^{\text {th }}$ leading causation of global mortality in all age groups. Significantly higher fatality rate (per 100) observes in nation abide by high pigment indexation, among youngster in Chad (0.5), Central Africa (0.38) and Niger (038) whereas oldster in Kenya (1.9) and Central African Republic (1.3). (30)

Natural increase is conspicuous in hot regions than in cold territories. The estimated natural increase in Swarthy is approximately $100 \%$ above the Caucasians. (1) Deep Pigmentation executes a $60 \%$ high fertility rate than light pigmentation. (1) The observe birth rate in African territories equals 4 to 5 times the death rate, whereas European States experiences the inverse. (1)

The study selects only a few States exhibiting desired characteristics subjects to limitation. Have ascertained more significant finding considering a large sample size, employing random sampling, and avoiding selection bias.

A study considering the above finding tends to propound interventions steering the foremost approach towards preventive care. Embraces health investments conforming populace early age nutrition 
and nourishment requisites, ensuring desired later age health benefits.

\section{Conclusion}

The health states inordinately servile to phenotypes, the stature and pigmentation, derives of internal and external exposures. The prolong healthy life span, associates positively and pejoratively to stature and pigmentation, respectively.

The increase vulnerability of statures to cardiac and cancer diseases, while pigmentations prone to influenza/pneumonia, and HIV/AIDS.

Enforcement of measures mitigating populace internal and external exposure can elicit desire output in phenotype and outcomes in health status.

\section{References}

1. World Life Expectancy . Health Profile [Internet]. US: 2018 [cited 2019 March] Available at :http:/ / www.worldlifeexpectancy.com/

2. Science Learning Hub. Genotype and phenotype [Internet].Newzealand: The University of Waikato; 2011 [cited 2019 March] Available at: https://www.sciencelearn.org.nz/resources/207genotype-and-phenotype

3. Douglas B. Dark Skin Is Very Good for You! A Scientific Review[Internet]. Africa Resource Center;2014 January[cited 2019 March].Availble at: https://www.africaresource.com/sci-tech-abusiness/genetics/479-dark-skin-is-very-good-for-youa-scientific-review

4. Mead MN. Benefits of Sunlight: A Bright Spot for Human Health. Environ Health Perspect. 2008 May; 116(5): A197. Available from : https:/ / doi.org/10.1289/ehp.116-a160

5. Varanasi A. 4 health advantages of being a short person you didn't know about [Internet].India:The Health Site; 2016. [cited 2019 March] Available at: http://www.thehealthsite.com/diseasesconditions/health-advantages-of-being-a-short-personyou-didnt-know-about-v0516/

6. NCD Risk Factor Collaboration (NCD-RisC), et al. A century of trends in adult human height. Elife. $2016 \mathrm{Jul}$ 26;5.Available from: https:// doi.org/10.7554/eLife.13410.002

7. RPD. IQ Correlation to Skin Tone Across the World [Image on internet]. Reddit.com; 2016 [ cited 2019 March]Available https://www.reddit.com/r/DarkEnlightenment/com ments/4xhfm $4 /$ iq_to_skin_tone_correlation_across_the _world/

8. Omondi S. What is a rate of natural increase? [Internet]. World atlas; 2017 October [ cited 2019 March]Available at: https://www.worldatlas.com/what-is-a-rate-ofnatural-increase.html

9. NCD-RisC. HEIGHT [Internet].Lancet; 2016 [cited 2019] Available at : http://www.ncdrisc.org/datadownloads-height.html

10. Hagos J. Human Displacement Map of the World,2008. [Image on Internet]. Maps on the Web; 2016 May [cited 2019 March] Available at https:/ / mapsontheweb.zoommaps.com/image/144554073735

11. Weather-Atlas. Monthly weather forecast and Climate [Internet]. 2018[ cited 2019 March]Available at: https://www.weather-atlas.com/en

12. FAO,IFAD,UNICEF,WEP and WHO.The state of food security and nutrition in the world 2017.Building resilience for peace and food security. Rome:FAO; 2017.132p, ISBN 978-92-5-109888-2

13. Irfan U. Cold weather or hot weather: which one is more deadly [Internet]. VOX; 2018 January [cited 2019 March]Available at: https://www.vox.com/energyand-environment/2018/1/17/16851398/cold-snapheat-wave-deaths-human-health.

14. World Data.Info. Body size by country [Internet]. 2019 [cited 2019 March] Available at: https://www.worlddata.info/average-bodyheight.php

15. Cavazos M. What Makes People Grow Taller? [Internet]. Healthfully; 2018 December [cited 2019 March] Available at : https://healthfully.com/what-makespeople-grow-taller-4958333.html

16. Akombi BJ, Agho KE, Merom D, Renzaho AM, Hall JJ. Child malnutrition in sub-Saharan Africa: A metaanalysis of demographic and health surveys (2006-2016). PLoS One. 2017;12(5):e0177338. Available from: https://doi.org/10.1371/journal.pone.0177338

17. Boseley $S$.Taller people more likely to get cancer, say researchers [Internet]. Sweden: The guardian; 2015 October [ cited 2019 March]Available at: https://www.theguardian.com/society/2015/oct/01/t aller-people-more-likely-to-get-cancer-say-researchers

18. Wells J. The five surprising health benefits of being short[Internet].UK: The Telegraph; 2015 October [cited 2019 March]Available at: https://www.telegraph.co.uk/men/active/mens-

health/11906258/The-five-surprising-health-benefits-ofbeing-short.html

19. Wang F, Xu X, Yang J, Min L, Liang S, Chen Y. (2017). Height and lung cancer risk: A meta-analysis of observational studies. PloS one. 2017; 12(9): e0185316. Available from: https://doi.org/10.1371/journal.pone.0185316

20. Roetker NS, Armasu SM, Pankow JS, Lutsey PL, Tang $\mathrm{W}$, Rosenberg MA, et al. Taller height as a risk factor for venous thromboembolism: a Mendelian randomization meta-analysis. J Thromb Haemost. 2017;15(7):1334-1343. Available from: https://doi.org/10.1111/jth.13719

21. Science chat forum. Global Population by Race \& The Future of Our World [Internet]. 2010 [cited 2019 March]Available 
http:/ / www.sciencechatforum.com/viewtopic.php?f=8 $2 \& \mathrm{t}=16165$.

22. Staughton J. Why Do People Have Different Skin Colors? [Internet]. Science ABC; 2016 [cited 2019 March] Available at:https://www.scienceabc.com/humans/why-somepeople-fair-others-dark-skin-color-determine.html

23. Herrera AS, Leszek J, del Carmen Arias Esparza M, Solís-Arias RI, Solís-Arias PE, et al. Human Photosynthesis and Alzheimer's Disease. Pharmaceut Anal Acta. 2012; S15. Available from: https://doi.org/10.4172/2153-2435.S15-00

24. Sauer A. Alzheimer's May Affect Races Differently [Internet]. US: Alzheimers.net; 2017 September [cited 2019 March]Available at: https://www.alzheimers.net/9-2-15-alzheimers-mayaffect-races-differently/

25. Harris SS. Vitamin D and African Americans.The Journal of Nutrition. 2006;136( 4):1126-1129,Available from: https://doi.org/10.1093/jn/136.4.1126

26. Jiménez-Sousa MA, Martínez I, Medrano LM, Fernández-Rodríguez A, Resino S. Vitamin D in Human Immunodeficiency Virus Infection: Influence on Immunity and Disease. Front Immunol. 2018; 9:458.
Available

from: https://doi.org/10.3389/fimmu.2018.00458

27. Sambala EZ, Mdolo A, Banda R, et al. Burden of seasonal influenza in sub-Saharan Africa: a systematic review protocol. BMJ Open 2018 ;8: e022949. Available from: https://doi.org/10.1136/bmjopen-2018-022949

28. Cannell JJ, Vieth R, Umhau JC, Holick MF, Grant WB, Madronich S,et al. Epidemic influenza and vitamin D. Epidemiol Infect. 2006; 134(6):1129-40.Available from: https://doi.org/10.1017/S0950268806007175

29. Talachian, E., Bidari, A., Noorbakhsh, S., Tabatabaei, A., Salari, F. Serum levels of vitamins A and D, and zinc in children with acute diarrhea: A cross-sectional study. Medical journal of the Islamic Republic of Iran. 2015; 29:207.

30. Souchera S. Studies: Diarrheal disease rates vary across Africa, world [Internet]. Center for Infectious Disease Research and Policy - University of Minnesota; 2018 September [cited 2019]Available at: http:/ / www.cidrap.umn.edu/newsperspective/2018/09/studies-diarrheal-disease-ratesvary-across-africa-world 